\section{Tomasz Grzegorczyk}

https://orcid.org/0000-0002-4286-5753

Department of International Management Poznań University of Economics and Business Poznań, Poland tomasz.grzegorczyk@ue.poznan.pl

\section{Robert Glowiński}

Rotho AG

Wurenlingen, Switzerland

glowinski.r@gmail.com

\title{
Patent management strategies: A review
}

Accepted by Editor Ewa Ziemba | Received: June 28, 2019 | Revised: December 15, 2019; April 3, 2020 | Accepted: April 22, 2020.

\begin{abstract}
Aim/purpose - Intellectual property right management plays an increasingly important role in firms' business strategies. While empirical findings prove that strategic intellectual property management is positively correlated with multiple dimensions of firm performance, those competences are still rare. The research on the strategies of patent management is dispersed. Therefore, the aim of this paper is to present an analysis of the main patent strategies.

Design/methodology/approach - The method used in this paper is a narrative literature review in the area of strategic technology management.

Findings - This analysis of the most advisable patent strategies may allow its users to identify the best strategy in the given circumstances. The main patent strategies are: offensive, defensive and leveraging strategy.

Research implications/limitations - This analysis may be of importance not only for researchers dealing with technology and intellectual property management but also for firms willing to efficiently capture the value of their patent rights. A limitation of this literature review is the relatively small number of empirical studies in this area of strategic management.

Originality/value/contribution - This paper fills the research gap of the strategic choices left to managers in high-tech firms. The originality and value of this paper stem from the comprehensive analysis of patent strategies. Each of the presented strategies has their pros and cons in a given situation, illustrated by the presented cases. The choice between them should be made taking into account the enumerated factors.
\end{abstract}

Keywords: patent management, intellectual property, strategy, technology management, knowledge management.

JEL Classification: O32; 034; L24. 


\section{Introduction}

According to Czakon's research (2010), the focus has recently transferred from the sources of value and their formation, to their protection and appropriation. As a consequence, strategic intellectual property (IP) management has gained importance and, according to the resource-based view, a competitive advantage can be created thanks to the difficulties in imitation (Peteraf, 1993; Rumelt, 1987). Meanwhile, IP rights serve to prevent imitating. Therefore, they are vital for obtaining a sustainable competitive advantage in high-tech sectors (Teece, Pisano, \& Shuen, 1997). Moreover, IP rights management plays an increasingly important role in firms' business strategies. While the need to combine technology development strategies with the business model was lately highlighted by researchers, it was only in recent years that the third element of value creation gained momentum - the strategic IP management (Di Minin \& Faems, 2013). Empirical findings prove that IP management is positively correlated with multiple dimensions of firm performance (Somaya, 2012).

The number of patents granted contributes positively to company's financial performance (Maresch, Fink, \& Harms, 2016). However, it is not the size of a firm's patent portfolio, but the patent management capabilities that limit the value created by patents (Somaya, 2016). Such competences within firms are still rare, which leads to an ineffective management of intellectual property (IP) assets (Soranzo, Nosella, \& Filippini, 2017). While several years ago, patent protection used to be a matter of concern for lawyers, and was mainly discussed in the legal literature (e.g. Durham, 2018; Szczepanowska-Kozłowska, Promińska, \& Nowińska, 2014; Traple, 2017), nowadays it is a topic greatly related to strategic management (Fisher \& Oberholzer-Gee, 2013; Holgersson \& Wallin, 2017). As such, it has also recently gained academic interest. However, apart from the Somaya's (2012) analysis, the research on this issue is dispersed. Therefore, there is a need to analyse the notions in the literature concerning major patent strategies, which is the aim of this paper. Four specific research aims are also formulated:

1. Identify possible measures of introducing each of the strategies (substrategies).

2. Assess when each of the strategies may be beneficial.

3. Illustrate each strategy with a successful example of its introduction.

4. Propose future research directions.

This paper includes the following sections: literature review, research methodology and research findings, and discussion. In the latter section, three main patent strategies are analysed: offensive, defensive and leveraging. Then follows the future research section. The paper ends with a conclusion. 


\section{Literature review}

Intellectual property should be treated as an asset which value should be maximised (Palfrey, 2011). Among others, it can be used to secure the freedom to operate, create and sell products and services (Granstrand, 2000), raise funds or find a business partner, create a branch standard, divest or signal the technological superiority of the firm (Granstrand, 2010; Holgersson, 2012; Peters, Thiel, \& Tucci, 2013; Reitzig, 2004). IP also enables the commercialisation of technology through cooperation with other firms, e.g. through a license or strategic alliance.

Consequently, firms are forced to develop an IP strategy within the scope of the firm's innovation management. The strategy may be considered as a 'safety fence', within which a company moves. It demonstrates the objectives and the direction of their impact on an enterprise, as well as possible ways to reach them. A patent strategy, however, provides answers to questions related to the purpose of patenting, general goals to be achieved, which market and product areas should be covered by IP and what kind of methods, expenses and risks are involved.

In order to create a competitive advantage, the patent strategy has to be coherent with, tailored to, and formed on the basis of the corporate strategy, which comprises a product strategy, business unit and technology policy. The objective is the alignment of the IP rights portfolio with the key success factors of the company's strategy, such as: available resources and capabilities, approach to product development and commercialisation of technology, competitive situation, position on the market, product portfolio, R\&D effectiveness, product and technology life cycle, potential or existing cooperation in the sector, industry specifics, company's size and other (Al-Aali \& Teece, 2013; Gassmann \& Bader, 2011; Kasprzycki, Matczewski, Okoń-Horodyńska, du Vall, \& Wisła, 2008; Leone \& Laursen, 2011).

When considering patent strategies, it is necessary to distinguish their two different forms: strategic patenting and traditional patenting. The former form covers 'patent strategies that are used by firms to extend the function of patents beyond exclusive use', while according to the latter form 'the traditional function of a patent is to provide firms with an exclusive right to commercialise or license a patented invention' (Arundel \& Patel, 2003, p. 3). Somaya (2002, p. 3) defines a patent strategy as 'the pursuit of competitive advantages through the acquisition and management of patents by firms'. Patent information may also be used for strategic planning purposes by creating an integrated system of patent intelligence in supporting decision-making in R\&D investments (Baglieri \& Cesaroni, 2013). 
Strategic management is the art of choosing between various available options (Polowczyk, 2014). Sometimes the options are mutually exclusive, but they may often be used at the same time. The same applies to IP management strategies. Patent strategies cover a whole gamut of 'resource allocation decisions and logics of decision making' considering patent rights which are integrated within three main independent domains of actions (Somaya, 2012): (1) rights - understood as all actions concerning patent acquisition and maintenance; (2) enforcement - understood as (a) the use of threats of litigation to discourage rivals from using one's property rights or force them to pay royalties, or as (b) the monitoring of markets for counterfeited products and the enforcement of a patent law in order to avoid losses; (3) licensing - all measures related to patent sharing and methods of patent exploitation (incl. external patent exploitation).

\section{Research methodology}

The method used in this paper is a narrative literature review in the area of strategic management. The research presented in this paper is conceptual. Such an analysis allows the identification and analysis of the most advisable patent strategies. In order to achieve this aim, we searched these databases: Emerald, ProQuest and ScienceDirect, as well as Google and Google Scholar. The following phrases were used: patent management, IP management, patent strategy, IP strategy. We narrowed down the years of publications to 1990-2019 due to the fact that patent management strategies were firstly researched in a more systematic manner in the 1990s. In the first round of article selection, we read the abstracts and selected those articles which seemed to be in line with the aim of our study. We put focus on empirical and case study articles, but we did not limit our study to such studies. This way, we selected 33 journal articles. Then, we selected those publications which focused on the specific types of patent strategies (offensive, defensive and other). We also used the publications (papers, books and book chapters) referenced in the analysed articles. This method let us narrow down the number of cited publications to 46 .

\section{Research findings and discussion}

The main journals identified in the research area are: Management Decision (4 papers), Research Policy (4 papers), California Management Review (3 papers). 
Patent strategies may be divided into offensive and defensive, according to their orientation and aggressiveness. Gassmann \& Bader (2011) identify also preventive strategies, whereas Somaya (2012) enumerates leveraging strategies, which both are independent policies, but these approaches are rather exceptional. The offensive and defensive strategies are broadly demonstrated in patent-related literature; however, they are in part differently understood by scholars. Furthermore, the broad range of studies on the topic led to a creation of many different terms often concerning the same attribute. This refers, for example, to the term 'blocking', which can be associated with both offensive and defensive strategies. Defensive blocking aims at safeguarding firm's own technological room for manoeuvre against the competition, while offensive blocking strategy hinders competitors from applying technological developments (Blind, Edler, Frietsch, \& Schmoch, 2006).

It is worth noting that it is not the only possible division of patent strategies. Fisher \& Oberholzer-Gee (2013) analyse patent management strategies from the perspective of an enterprise that either owns these assets or does not. The following possibilities are open to patent owners: use of market power, sales, licensing, cooperation, and donation of IP rights. It often happens that companies plan to engage in a patent-rich industry, but do not own such rights themselves. In such a situation, a company usually faces the choice of the following strategies: gaining freedom of action, secrecy, developing alternative technology, obtaining a license from the rights holder and acquiring these rights to deter competition (Fisher \& Oberholzer-Gee, 2013).

\subsection{Offensive patent strategies}

Faix (1998) and Hentschel (2007) perceive an offensive strategy as a legal tool to limit the scope of competitors' intellectual property rights. Therefore, the basic goal of offensive strategies is to actively prevent competitors from obtaining a wide patent portfolio. Gassman \& Bader (2011, p. 40) define the offensive strategy as "a policy which bases on the strategic planning of IP right utilisation within the business activities of a company". In addition, it is stressed that patent rights ought to be proactively and aggressively put through. Moreover, 'preemptive patenting' in order to build patent fences turns out to increase firm valuation (Ceccagnoli, 2009).

Researchers distinguish various measures as elements of the offensive strategy. Somaya (2012) enumerates the following: (1) prevention from copying, (2) offensive blocking as well as the creation of fences (3), and offensive thickets 
(4). The main objective of all these activities is to assure that a broad scope of IP is legally protected. Therefore, the offensive blocking approach bases on submitting numerous patent applications for potential substitutes and the subsequent patent-based technology, in order to reduce the risk that the patents could be overturned.

Other means of action are direct activities against rival patent registrations, namely (5) opposition proceedings and (6) nullity proceedings, which are used in case of the poor effectiveness of patent protection, often caused by long patenting procedures and associated delays. This issue generally concerns industries with short innovation cycles. According to Somaya (2016), proprietary strategies are associated with delays in settlement during patent litigation but with faster adjudication.

When it comes to the differentiation from competitors, the utilisation of own patent rights to block rivals is the key to success. Furthermore, as a tactical manoeuvre, many companies register patents in order to mislead competitors (7). Such patents can be achieved without any major efforts and financial expenses but help to mislead rivals regarding the direction of own company's technological development. Some firms combine the strategy of patenting with protecting technology as a secret (Grzegorczyk, 2020). For example, in the first half of the 20th century, German firms Bayer and BASF were the leaders in the dye industry. At one time they patented individual components of the dye, but its exact, complete composition remained a secret. Another time, the result of a process was patented but without specifying the semi-finished products. Moreover, multiple inventions were patented in order to confuse competition, who was not able to establish a clear relation between the patented inventions and the products introduced to the market (Arora, 1997). Consequently, these companies were able to benefit from the quasi-monopolistic position.

One of the cases successfully using the offensive strategy began with Kodak ignoring the patent fence built by its smaller rival, Polaroid, around the technology of the instant image (Grzegorczyk, 2020). Kodak released a series of cameras using this technology, which resulted in Polaroid suing Kodak for patent infringement. The final verdict granted almost $\$ 1$ billion in damages and an order to close a $\$ 1.5$ billion factory employing 700 employees (Rivette \& Kline, 2001). 


\subsection{Defensive patent strategies}

According to Holgersson \& Granstrand's (2017) empirical study, the most frequent motive to patent is to protect product technology, followed by protecting the freedom to operate. Defensive strategies aim at minimising the effects on one's enterprise caused by IP-policies pursued by competitors. Hentschel (2007) emphasises the role of acquisition, maintenance and exploitation of company's own patent rights. Defensive measures can also be seen as a way of securing own patent rights against litigation. From a managerial point of view, defensive strategies make it more difficult for a rival to limit one's technological freedom. They also reduce the risk of infringement of foreign patents. Somaya (2012) summed it up as a viable strategy to protect one's freedom to operate by minimising the effects caused by foreign patent rights held by third parties. Empirical research shows that defensive strategies are linked with a faster settlement and adjudication in patent litigation (Somaya, 2016).

When a company is accused of patent infringements by a competitor, it ought to introduce a measure of the defensive strategy called the (1) 'mutual hold-up' (Gassmann \& Bader, 2011; Hentschel, 2007; Somaya, 2012). It means that the attacked company can, apart from other actions, use its own patent rights against products and business operations of the suing firm. Some patents are not created to be actively used, but rather they are treated as a kind of currency or bogey. For instance, in the semiconductor industry, the production costs are so enormous that halting the production process due to a court order to secure a claim, even for a short time, is very costly (Reitzig, 2004). This may even lead to a situation when in spite of the infringement of IP rights, the firm decides not to file a lawsuit for the fear of counterclaim and securing it. In order to be protected from such actions, it is necessary to be 'armed' with the IP that competitors use (Grzegorczyk, 2020). Mutual checkmating can be normalised in the form of cross-licensing deals. An example from 1998 would be the actions of a S3 company from the graphics processor industry, whose development was blocked by the Intel's patent fence (Rivette \& Kline, 2000).

An (2) extensive patent registration policy (defensive blocking) is a particularly important element of the strategy, which aims at securing the broadest scope of technology. Another division into qualitative and quantitative accumulation comes out of this policy. The first term is related to the protection of innovations which cannot be decomposed into fractions and easily patented around, e.g. inventions in the pharmaceutical industry. The quantitative aggregation is especially helpful in industries with high technological complexity, e.g. semi- 
conductors or medical engineering because each product innovation consists of numerous individual technologies. Such branches use the 'patent portfolio race', since an absolute number of patents is of high importance (Hentschel, 2007). Therefore, the significance of a patent obtained from external sources grows. Thus, in order to reduce the exposure to risk of infringing a third party, mutual deals concerning the exchange of patent rights are agreed upon. Cross-licensing is one of the few possibilities that enables the manufacturing process without carrying the risk of patent infringements (Grindley \& Teece, 1997). Comparing patent data on licensing and cross-licensing shows that firms may be reluctant to share their knowledge and IP with competitors without obtaining the same for themselves (Grzegorczyk \& Glowinski, 2017).

Somaya (2002, 2012), Hentschel (2007) as well as Gassmann \& Bader (2011) unanimously distinguish legal measures as part of the defensive strategy that ensures a company's freedom to operate. It is shown that through excellent dealing with information coming from the prior art principle, a company can carry out numerous legal opposition proceedings against competitive patents and repel attacks from competitors (3). A company whose patents were infringed has a chance to block a competitor from using them and receive financial compensation. This strategy requires, however, certainty and recognition of a patent infringement, which is in fact very difficult and cost-intensive in the long-term (Hentschel, 2007). There are various strategies to repel attacks of a third party which, according to Gassmann \& Bader (2011), focus on four principles:

1. Counterattack on the legal validity of the disputed patent (nullity suit).

2. Counter-remark, if the patent right violation exists, e.g. through a declaratory action.

3. Counterattack on a product, technology or service portfolio of the attacking company, by using own IP rights.

4. Further technical, legal and political steps influencing the infringement proceedings. Nevertheless, high costs involved in patent litigations have to be taken into account.

Another effective strategy is the (4) pre-emptive disclosure (e.g. blocking publications). The strategic disclosure is particularly advisable if a company cannot or does not want to patent the invention. While this strategy allows competitors to make use of the invention, it ensures that a company will not be deprived of the same. For example, Merck biotechnology company, together with the University of Washington, enabled public access to the human genome database. Thanks to the firm's high capabilities in R\&D as well as sales and marketing, greater technological progress within the sector was more valuable than the exclusivity based on patent rights (Pisano, 2006). The strategic disclosure is 
often advisable because of the lack of substantial costs associated with the patenting process. Moreover, the pre-emptive disclosure does not involve the necessity to wait for obtaining patent and it is recognised worldwide. Furthermore, such a disclosure may cover a much broader scope of the technology than a patent, limiting the risk of its circumvention (Peters, Thiel, \& Tucci, 2013).

To obtain and maintain the freedom of action, the following measures can also be undertaken: (6) in-licensing or (7) cross-licensing, as well as (8) an invalidation of interfering patents (Gassmann \& Bader, 2011). For example, Belingheri \& Leone (2017) demonstrate that many start-up companies license-in from other firms, which illustrates that this practice is more widespread than the literature would suggest.

Among defensive strategies, preventive measures are eminent (Gassman \& Bader, 2011). Companies focus on developing technologies which do not infringe patent rights. They should strive to pursue the goal of freedom of action by carrying out preventive measures during the development of products and technology. This, in turn, means that the IP activities of competitors ought to be observed, regularly analysed and certain solutions should be developed within a company in case of an external threat. However, this so-called patent clearing strategy entails expenditure of time and high costs. A legal protection strategy can keep its preventive character against a third party, when a fundamental readiness to enforce those IP rights is credible. The value of a patent drops when a competitor infringes it and the patent owner tolerates it knowingly or unknowingly.

Somaya (2012) notices that the defensive strategy has limitations and in some instances such an approach will no longer be viable. This may happen if the patentee is a 'hidden champion' (a niche specialist) and the focal firm's patent portfolio does not cover technologies in that niche.

Firms often pursue hybrid patent strategies which consist of both offensive and defensive measures (Gassmann \& Bader, 2011). Examples of enterprises which take advantage of both approaches are the electric engineering corporation Siemens and the software producer Microsoft. Despite the fact that both firms fundamentally follow offensive IP strategies, they also focus on defensive policies to minimise the impact of foreign patents on their own performance.

\subsection{Leveraging patent strategy}

Furthermore, the leveraging patent strategy should be considered independently. Patents may be leveraged strategically in the company's external relationships to advance its strategic objectives (Trigeorgris \& Baldi, 2010). The 
core essence of the leveraging strategy is to take advantage of the bargaining advantages conferred by the exclusionary power of patents, and thus directly or indirectly generate income (Schmeisser \& Mohnkopf, 2008), even if the possessed, distinctive patent right is not suitable for a pursuit of an offensive or a defensive strategy. A patent may be granted within the technology, which is not the core focus of the strategy or does not refer to firms' central competences, but can nevertheless be a precious tool providing a chance to generate extra returns.

The improvement of the bargaining power during negotiations is an example of embracing the leveraging patent strategy. While using this strategy, it is not necessary for a company to patent every substitute technology or to have impermeable patent protection (Somaya, 2012). While these can be helpful, it is crucial to obtain patent coverage on a significant technology that other firms are using or will use in the future. Therefore, it would be difficult to 'work around' such patents, which allows the creation of a strategic advantage in negotiations.

Broadly understood licensing belongs to the direct profit opportunities of a leveraging policy. Cross-licensing is particularly advisable when both parties want to take mutual advantage of their technology without spending capital or risking litigation (Grimaldi, Cricelli, \& Rogo, 2018; Hall \& Ziedonis, 2001). For example, Microsoft and Nikon concluded cross-licensing agreement which enabled both firms to innovate openly with each other's technologies, bringing new features and products to the market (Trigeorgris \& Baldi, 2010). Furthermore, Chesbrough \& Chen (2013) show on the example of the pharmaceutical sector how profitable it can be to license the firm's discarded IP in the form of invented substances that have been incorrectly classified as useless.

Other opportunities for patent leveraging may also arise. One of the main motives of joint ventures and strategic alliances is the co-creation of technical standards in an industry (similarly as in the case of patent pools), as they allow the creation of a sustainable competitive advantage (Holgersson, 2012). Delerue's empirical study (2018) shows that joint patenting may be designed to hold the other party hostage as a means to ensure partnership continuity.

A 'patent troll' (non-practicing entity, NPE) is a notorious type of a firm using the leveraging strategy (Reitzig, Henkel, \& Heath, 2007). 'Patent trolls' do not commercialise technologies on their own and are consequently protected from defensive strategies based on blocking patent portfolios and mutual holdup, which makes them especially dangerous (Somaya, 2012). Due to the fact that small companies are particularly vulnerable to measures taken by NPEs, in order to avoid or minimise damage caused by a patent, they should be proactive - 
preventive measures should be taken which should help to determine whether such an invention has already been granted a patent right and insurance from infringement lawsuits should be purchased.

Patenting may also be aimed at signalling the quality of a firm and its research to investors, business partners and competitors. Certified research quality may further lead to discouraging competitors from competing in a certain research area and to encouraging licencing the patented invention.

\section{Future research directions}

Patent management strategies still remain an underresearched area, therefore the future research directions are vast. Hybrid strategies are particularly rarely presented in the literature, while it seems that they are quite often undertaken in practice. Therefore, one could dwell into the motives of combining particular offensive, defensive and leveraging strategies. Moreover, empirical research on the effectiveness of various strategies in given industries should be another direction of future research.

A possible area of future research concerns the interplay between the generic strategies. Somaya (2012) noticed that researchers could study how a changing portfolio of patents affects the firm's licensing and enforcement choices. For example, the question arises if stronger patent portfolios lead companies to cross-license patents less and enforce them more in an attempt to move from the defensive strategy toward proprietary and leveraging strategies.

In terms of offensive strategies, it is worth examining how common and effective are specific measures and compare them with each other (e.g. nullity and opposition proceedings). Leveraging strategies are similarly under researched in this area. A question which arises is how common and effective are leveraging strategies, such as signalling technological superiority by a vast patent portfolio? Who is it usually aimed at (business partners, investors, competitors)?

Furthermore, there is still a lack of research on defensive strategies that would dwell into Somaya's (2012) proposal on examining which defensive strategies are used by firms when portfolio patenting and mutual holdup do not work, and how effective they are. 


\section{Conclusions}

Proper patent management allows firms to appropriate value from R\&D activities and achieve sustainable competitive advantage. With the rising competition in the high-tech sectors, patent management skills are becoming more vital than the firm's patent portfolio (Somaya, 2016). However, patent management competences are still scarce.

This paper contributes to the strategic management literature, as it reviews the main notions of the literature on patent strategies. While the structure of the paper draws from Somaya's (2012) division of generic patent strategies into offensive, defensive and leveraging strategies, it also relies on other research and updates the issue in question.

Pursuing the specific goals, this paper identifies possible measures of introducing each of the strategies (sub-strategies), assesses when each of the strategies may be beneficial and illustrates each strategy with a successful example of its introduction. Future research directions are also indicated.

This analysis of the most advisable patent strategies helps identify the best strategy in the given circumstances. Firms should concentrate on adjusting patent management in accordance with their needs, awareness, capabilities, overall strategy as well as their business model, organisational conditions, and competitive environment. This analysis may be of importance not only to researchers dealing with intellectual property management, but also to the firms willing to capture the value of their patent rights efficiently. While the paper may not be a roadmap of every possible strategy, it links different strategies, their aims and ways of their implementation.

A limitation of this literature review is a relatively small number of empirical studies in this area of strategic management. Furthermore, the literature review is based on the prior, dispersed research. Moreover, it is not a comprehensive study and does not exhaust all sub-strategies and determinants of their successful introduction. This research was also undertaken by a single author. As a consequence, it may be biased in terms of the selection of articles, their review and synthesis. 


\section{References}

Al-Aali, A. Y., \& Teece, D. J. (2013). Towards the (strategic) management of intellectual property: Retrospective and prospective. California Management Review, 55(4), 15-30. https://doi.org/10.1525/cmr.2013.55.4.15

Arora, A. (1997). Patents, licensing, and market structure in the chemical industry. Research Policy, 27(4-5), 391-403.

Arundel, A., \& Patel, P. (2003). Strategic patenting. Background report for the Trend Chart Policy Benchmarking Workshop: New Trends in IPR Policy, Luxembourg.

Baglieri, D., \& Cesaroni, F. (2013). Capturing the real value of patent analysis for R \& D strategies. Technology Analysis \& Strategic Management, 25(8), 971-986. https: //doi.org/10.1080/09537325.2013.823149

Belingheri, P., \& Leone, M. I. (2017). Walking into the room with IP: Exploring startups' IP licensing strategy. Management Decision, 55(6), 1209-1225. https://doi. org/10.1108/MD-04-2016-0227

Blind, K., Edler, J., Frietsch, R., \& Schmoch, U. (2006). Motives to patent: Empirical evidence from Germany. Research Policy, 33(5), 1583-1598. https://doi.org/ 10.1016/j.respol.2006.03.002

Ceccagnoli, M. (2009). Appropriability, preemption, and firm performance. Strategic Management Journal, 30, 81-98. https://doi.org/10.1002/smj.723

Chesbrough, H., \& Chen, E. L. (2013). Recovering abandoned compounds through expanded external IP licensing. California Management Review, 55(4), 83-101. https://doi.org/10.1525/cmr.2013.55.4.83

Czakon, W. (2010). Strategia jako reguły zawłaszczania renty ekonomicznej [Strategy as the rules of the economic rent appropriation]. In R. Krupski (Ed.), Zarzadzanie strategiczne. Strategie organizacji [Strategic management. Strategies organizations] (pp. 137-148). Wałbrzych: Wałbrzyska Wyższa Szkoła Zarządzania i Przedsię-biorczości.

Delerue, H. (2018). Shadow of joint patents: Intellectual property rights sharing by SMEs in contractual R\&D alliances. Journal of Business Research, 87(C), 12-23. https://doi.org/10.1016/j.jbusres.2018.02.002

Di Minin, A., \& Faems, D. (2013). Building appropriation advantage. California Management Review, 55(4), 7-14. https://doi.org/10.1525/cmr.2013.55.4.7

Durham, A. (2018). Patent law essentials: A concise guide. Santa Barbara, CA: Praeger.

Faix, A. (1998). Patente im strategischen marketing - Sicherung der Wettbewerbsfähigkeit durch systematische Patentanalyse und Patentnutzung. Berlin: Erich Schmidt.

Fisher III, W. W., \& Oberholzer-Gee, F. (2013). Strategic management of intellectual property: An integrated approach. California Management Review, 55(4), 157-183. https://doi.org/10.1525/cmr.2013.55.4.157 
Gassmann, O., \& Bader, M. A. (2011). Patentmanagement: Innovationen erfolgreich nutzen und schützen [Patent management: Successful protecting and profiting from innovations]. Heidelberg: Springer.

Granstrand, O. (2000). The economics and management of intellectual property: Towards intellectual capitalism. Northampton, MA: Edward Elgar.

Granstrand, O. (2010). Industrial innovation economics and intellectual property. Gothenburg: Svenska Kulturkompaniet.

Grimaldi, M., Cricelli, L., \& Rogo, F. (2018). Auditing patent portfolio for strategic exploitation: A decision support framework for intellectual property managers. Journal of Intellectual Capital, 19(2), 272-293. https://doi.org/10.1108/JIC-012017-0019

Grindley, P. C., \& Tecce, D. J. (1997). Managing intellectual capital: Licensing and cross-licensing in semiconductors and electronics. California Management Review, $39(2), 8-41$

Grzegorczyk, T., \& Glowinski, R. (2017). Trends and strategies of patent exploitation analysis of empirical data. Modern Management Review, 22(24), 55-70. http://doi. prz.edu.pl/pl/pdf/zim/285

Grzegorczyk, T. (2020). Managing intellectual property: Strategies for patent holders. Journal of High Technology Management Research, https://doi.org/10.1016/ j.hitech.2020.100374

Hall, B. H., \& Ziedonis, R. H. (2001). The patent paradox revisited: An empirical study of patenting in the U.S. semiconductor industry, 1979-1995. The RAND Journal of Economics, 32(1), 101-128. https://doi.org/10.2307/2696400

Hentschel, M. (2007). Patentmanagement, Technologieverwertung und Akquise externer Technologien. Wiesbaden: Deutscher Universitäts-Verlag.

Holgersson, M. (2012). Innovation and intellectual property. Strategic IP management and economics of technology. Gothenburg: Chalmers University of Technology.

Holgersson, M., \& Granstrand, O. (2017). Patenting motives, technology strategies, and open innovation. Management Decision, 55(6), 1265-1284. https://doi.org/10.1108 /MD-04-2016-0233

Holgersson, M., \& Wallin, M. W. (2017). The patent management trichotomy: Patenting, publishing and secrecy. Management Decision, 55(6), 1087-1099. https://doi. org/10.1108/MD-03-2016-0172

Kasprzycki, D., Matczewski, A., Okoń-Horodyńska, E., du Vall, M., \& Wisła, R. (2008). Zarządzanie własnościa intelektualna $w$ przedsiębiorstwie - regulaminy korzystania $z$ wyników prac intelektualnych powstałych $w$ przedsiębiorstwie [Intellectual property management in a company - regulation of using the findings of intellectual works created in a company]. Kraków: Uniwersytet Jagielloński.

Leone, M. I., \& Laursen, K. (2011). Patent exploitation strategies and value creation. In F. Munari \& R. Oriani (Eds.), The economic valuation of patents. Methods and applications. Northampton: Edward Elgar. 
Maresch, D., Fink, M., \& Harms, R. (2016, November-December). When patents matter: The impact of competition and patent age on the performance contribution of intellectual property rights protection. Technovation, 57-58, 14-20. https://doi.org/10. 1016/j.technovation.2015.11.009

Palfrey, J. (2011). Intellectual property strategy. Cambridge, MA: MIT Press.

Peteraf, M. A. (1993). The cornerstones of competitive advantage: A resource-based view. Strategic Management Journal, 14(3), 179-191. https://doi.org/10.1002/smj. 4250140303

Peters, T., Thiel, J., \& Tucci, Ch. L. (2013). Protecting growth options in dynamic markets. California Management Review, 55(4), 121-142. https://doi.org/10.1525/ cmr.2013.55.4.121

Pisano, G. (2006). Profiting from innovation and the intellectual property revolution. Research Policy, 35(8), 1122-1130. https://doi.org/10.1016/j.respol.2006.09.008

Polowczyk, J. (2014). Zarządzanie strategiczne jako wielowymiarowa przestrzeń paradoksów [Strategic management as multidimensional space of paradoxes]. Studia Oeconomica Posnaniensia, 2(2), 107-125.

Reitzig, M. (2004), Strategic management of intellectual property. MIT Sloan Management Review, 45(3), 35-40. Retrieved from https://sloanreview.mit.edu/article /strategic-management-of-intellectual-property/

Reitzig, M., Henkel, J., \& Heath, C. (2007). On sharks, trolls, and their patent prey unrealistic damage awards and firms' strategies of being infringed. Research Policy, 36(1), 134-154. https://doi.org/10.1016/j.respol.2006.10.003

Rivette, K. D., \& Kline, D. (2000). Discovering new value in intellectual property. Harvard Business Review, 78(1), 54-66. Retrieved from https://hbr.org/2000/01/ discovering-new-value-in-intellectual-property

Rumelt, R. P. (1987). Theory, strategy and entrepreneurship. In D. J. Teece (Ed.), The competitive challenge (pp. 137-158). New York: Harper \& Row.

Somaya, D. (2002). Theoretical perspectives on patent strategy. Working Paper, University of Maryland. Retrieved from http://citeseerx.ist.psu.edu/viewdoc/download ?doi=10.1.1.195.354\&rep=rep1\&type $=$ pdf

Somaya, D. (2012). Patent strategy and management: An integrative review and research agenda. Journal of Management, 38(4), 1084-1114. https://doi.org/10.1177/01492 06312444447

Somaya, D. (2016). How patent strategy affects the timing and method of patent litigation resolution. In J. M. De Figueiredo, M. Lenox, F. Oberholzer-Gee, \& R. Vanden Bergh (Eds.), Strategy beyond markets. Advances in strategic management (Vol. 34, pp. 471-504). https://doi.org/10.1108/S0742-332220160000034014

Soranzo, B., Nosella, A., \& Filippini, R. (2017). Redesigning patent management process: An action research study. Management Decision, 55(6), 1100-1121. https:// doi.org/10.1108/MD-04-2016-0226 
Schmeisser, W., \& Mohnkopf, H. (Hrsg.). (2008). Ausgewählte Beiträge zum Innovationsmanagement, zur empirischen Mittelstandsforschung und zum Patentschutz. München und Mering: Rainer Hampp Verlag.

Szczepanowska-Kozłowska, K., Promińska, U., \& Nowińska, E. (2014). Własność przemystowa $i$ jej ochrona [Intellectual property and its protection]. Warszawa: Lexis Nexis.

Teece, D. J., Pisano, G., \& Shuen, A. (1997). Dynamic capabilities and strategic management. Strategic Management Journal, 18(7), 509-534. https://doi.org/10.1002/ (SICI)1097-0266(199708)18:7<509::AID-SMJ882>3.0.CO;2-Z

Traple, E. (2017). Prawo patentowe [Patent law]. Warszawa: Wolters Kluwer.

Trigeogris, L., \& Baldi, F. (2013). Patent strategies: Fight or cooperate? Real Options Annual Conference, Tokyo, 25-26 June. 